\title{
カーボンチップを用いる真空融解法によるニッケル, コバルト中の微量酸素定量
}

\author{
斉藤 守正，須藤 恵美子*
}

(1974 年. 9 月 6 日受理)

電解をたはゾーン精製した高純度ニッケル,コバルト中の微量酸素を真空融解法で検討を行った。

鉄浴法，空浴法では精度がわるく，低値を与えたので，新しくカーボンチップを添加する方法を検討 し良好な結果を得た。試料は (2〜3)g を用い，(16〜20)メッシュの粒度のカーボンチップ $0.5 \mathrm{~g}$ を試

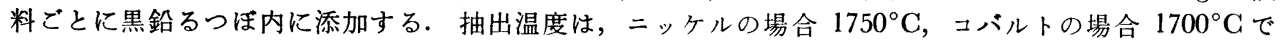
それぞれ 5 分間抽出定量を行う。

本法による繰り返し精度は, 電解ニッケル（酸素含有量 $7.6 \mathrm{ppm})$, ゾーン精製したニッケル（酸素

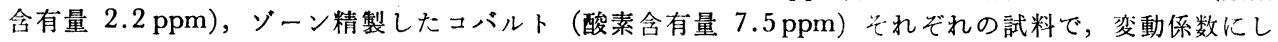
て $5.6 \%, 18.6 \%, 9.4 \%$ であった.

\section{1 緒言}

ニッケル中の酸素定量には，真空融解法で鉄浴法，女 るいは金属浴を用いない dry crucible 法 (ここでは空 浴法と呼ぶ) で $(1500 \sim 1700)^{\circ} \mathrm{C}$ の温度で抽出定量する 方法の報告がある1) 3)。 また，コバルト中の酸素定量に 関しては，鉄浴法で $(1550 \sim 1600){ }^{\circ} \mathrm{C}$ の温度で抽出定量 する方法が報告されているにすぎない1).

電子管材料用ニッケル，あるいはゾーン精製したニッ ケル，コバルト中の酸素含有量は $10 \mathrm{ppm}$ 以下であるの で微量酸素の定量法の確立が必要になってきた.ニッケ ル, コバルト中の数 ppm の微量酸素を 精度よく定量す るには，装置の検出感度上，あるいは黒鉛るつぼ類から 発生するから試験值の影響を小さくする上で分析試料を $2 \mathrm{~g}$ 以上採取する必要があった。そこで上述の鉄浴法, 空浴法の検討を行ったが，それらの方法は， $2 \mathrm{~g}$ 以上の 試料を黒鉛るつぼ内に投入定量していくと低值を与え， しかも抽出時間が長くなる傾向があり, 微量酸素を定量 するには難点があった・そこで著者らは試料と常に新し いカーボンと接触するカーボンチップを用いる真空融解 法をニッケル, コバルト中の微量酸素定量に応用した結 果，良好な結果が得られたので報告する.

\section{2 実験方法}

\section{1 装}

使用した装置は，離合社製定容測圧式金属中ガス分析 * 金属材料技術研究所 : 東京都目黑区中目黑 2-3-12
装置 S.H. O.-II 型である. 感度は酸素にして 0.0055 $\mathrm{mg} / \mathrm{mm}$ oil である. るつほ類は，日本学術振興会鉄鋼 ガス分析協議会で検討され脱ガス時間が短時間で酸素の から試験值が小さくなることが認められた大和田カーボ ン工業製で, 内径 $20 \mathrm{~mm} \phi$, 深さ $70 \mathrm{~mm}$ の大きさの材質 OT2400 の黑鉛るつほ，粮度 200 メッシュの材質 P2400 の黒鉛粉末をそれぞれ使用した.

\section{2 試料及び試料調製}

使用した試料は，市販電解二ッケルとコバルト，モン ド，あるいは Johnson Matthey 製高純度ニッケルとコ バルト，それらをゾーン精製したものである. その化学 成分を Table 1 に示す. 分析試料は上述供試体から油 中電動カッター, またはのこぎりで切断し, やすり,つ いで電解研摩法によって表面処理を行った. 電解研摩 は次の条件で行った. ニッケルの場合, 電解液は過塩素 酸 $(28 \%)$-永酷酸 $(1: 10 \mathrm{v} / \mathrm{v})$, 対陰極にステンレス 板, 電圧 $60 \mathrm{~V}$, 電流密度 $10 \mathrm{~A} / \mathrm{dm}^{2}$, 温度は $(20 \sim 25)$ ${ }^{\circ} \mathrm{C}$ の範囲の条件で 5 分間研摩した. コバルトの場合, 電解液はりン酸-硫酸 $(3: 1 \mathrm{v} / \mathrm{v})$, 刘陰極にステンレス 板, 電圧 $1.5 \mathrm{~V}$, 電流密度 $(5 \sim 10) \mathrm{A} / \mathrm{dm}^{2}$, 温度 $(20$ 〜25) ${ }^{\circ} \mathrm{C}$ の条件で 3 分間研摩した. 電解後, 水, エチル アルコール, 石油ベンジンで洗浄後直ちに分析した。

\section{3 定量方法}

黒鉛るつぼをハンマーで砕いて作った粒度（16〜20) メッシュの範囲のカーボンチップをあらかじめ黒鉛るつ ぼ内に $3 \mathrm{~g}$ 入れておき, $(2200 \sim 2300)^{\circ} \mathrm{C}$ の温度で 5 時 
Table 1 Chemical composition of samples

\begin{tabular}{|c|c|c|c|c|c|c|}
\hline Sample & C $(\%)$ & $\mathrm{Fe}(\%)$ & Co or $\mathrm{Ni}(\%)$ & $\mathrm{Si}(\%)$ & $\mathrm{Cu}(\%)$ & $\mathrm{Al}(\%)$ \\
\hline \multicolumn{7}{|l|}{ Mond nickel, $\mathrm{Ni}-1$} \\
\hline Electrolytic nickel, $\mathrm{Ni}-2$ & 0.0070 & 0.0007 & Co $<0.003$ & & 0.001 & \\
\hline Johnson Matthey nickel, Ni 3 & 0.0047 & 0.0008 & & $<0.0003$ & $<0.0001$ & \\
\hline Zone melted nickel (in hydrogen), $\mathrm{Ni}-4$ & 0.0020 & & & & & \\
\hline Electrolytic cobalt, Co-1 & 0.020 & 0.07 & 0.05 & & & \\
\hline Johnson Matthey cobalt, Co-2 & & 0.0003 & & 0.0003 & $<0.0001$ & $<0.0001$ \\
\hline Zone melted cobalt (in vacuum), Co 3 & 0.010 & & & & & \\
\hline
\end{tabular}

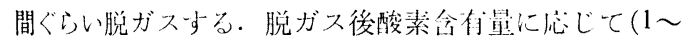
3)g の試料を投入するが，数 ppm の酸素含有荲の場合 には $2 \mathrm{~g}$ 以上を投入する. 酸素抽出温度はニッケルの場 合 $1750^{\circ} \mathrm{C}$, コバルトの場合 $1700^{\circ} \mathrm{C}$ でそれぞれ 5 分間 抽出定量する。定量後, カーボンチップ約 $0.5 \mathrm{~g}$ をボー ト状に作ったブリキ板で投入し，るつぼ温度を $2000^{\circ} \mathrm{C}$ にして数分間脱ガスする.十分から試験值が小さくなれ ば再びるつぼ温度を酸素抽出温度に下げ, 次の分析試料 を投入定量する.以下この操作を繰り返す。1 1個のるつ ぼで連続 10 個定量できる.

\section{3 実験結果及び考察}

\section{1 ガス抽出温度}

酸素分量では抽出温度が重要な因子であるのでまず 抽出温度と酸素抽出量との関係を調べた. 使用したカー ボンチップの粗度はフェロシリコン，金属ベリリウム川 の酸素定量で良好な結果が得られた $(16 〜 20)$ メッシュ の範囲のもの4) -6), 試料重量は約 $2 \mathrm{~g} /$ 月いる条件で検討 を行った。

ニッケルの場合, 試料 Ni-1, Ni-2 を用いて行ったと きの絬果を Table 2 に示す. 抽出温度 $1650^{\circ} \mathrm{C}$ で測定 すると，抽出時間を 10 分行っても酸素定量值は低值を 与皃たが，温度 $1700^{\circ} \mathrm{C}, 1750^{\circ} \mathrm{C}, 1800^{\circ} \mathrm{C}$ で測定する と, 酸素抽出量が高くなり, しかも約 5 分の抽出時間で 酸素の抽出が終了し, 精度よく定量できた. 従って, こ こでは $1750^{\circ} \mathrm{C}$ の抽出温度で定量することにした.

コバルトの場合もニッケルと同様, 試料 Co-1, Co-2 を用いて検討し，その結果を Table 3 亿示す. $1650^{\circ} \mathrm{C}$ $\sim 1800^{\circ} \mathrm{C}$ の各抽出温度で測定したが，ほとんど各温度 とも酸素抽出量が高い值が得られたが， $1650^{\circ} \mathrm{C}$ の温度 では怞出時間が 10 分かかり, しかも少し低い定量值が 得られる傾向があった・をた, $1700^{\circ} \mathrm{C}, 1750^{\circ} \mathrm{C}, 1800^{\circ} \mathrm{C}$ の各抽出温度では高い值が得られたが，“ゲッター作用” などの関係で低い温度で定量したほうが有利なので，こ こでは $1700^{\circ} \mathrm{C}$ の抽出温度で行うことにした。
Table 2 Effect of gas extraction temperature on oxygen values in nickel by vacuum fusion method with carbon chip

\begin{tabular}{|c|c|c|c|}
\hline Sample & $\begin{array}{l}\text { Gas extraction } \\
\text { temperature }\left({ }^{\circ} \mathrm{C}\right)\end{array}$ & $\begin{array}{l}\text { Gas extraction } \\
\text { time (min) }\end{array}$ & $\begin{array}{l}\text { Oxygen found } \\
\text { (ppm) }\end{array}$ \\
\hline $\mathrm{Ni}-\mathrm{I} \uparrow$ & $\begin{array}{l}1650 \\
1650 \\
1750 \\
1750 \\
1750 \\
1800 \\
1800\end{array}$ & $\begin{array}{r}10 \\
10 \\
5 \\
5 \\
5 \\
5 \\
5\end{array}$ & $\begin{array}{l}39 \\
37 \\
42 \\
44 \\
40 \\
42 \\
42\end{array}$ \\
\hline $\mathrm{Ni} \cdot 2 \dagger$ & $\begin{array}{l}1650 \\
1650 \\
1650 \\
1700 \\
1700 \\
1700 \\
1750 \\
1750 \\
1800 \\
1800\end{array}$ & $\begin{array}{r}10 \\
10 \\
10 \\
5 \\
5 \\
5 \\
5 \\
5 \\
5 \\
5\end{array}$ & $\begin{array}{c}6.2 \\
5.5 \\
6.5 \\
6.8 \\
8.0 \\
7.5 \\
8.1 \\
10 \\
7.9 \\
7.2\end{array}$ \\
\hline
\end{tabular}

$\dagger$ Sample taken: $2 \mathrm{~g}$

Table 3 Effect of gas extraction temperature on oxygen values in cobalt by vacuum fusion method with carbon chip

\begin{tabular}{|c|c|c|c|}
\hline Sample & $\begin{array}{c}\text { Gas extraction } \\
\text { temperature }\left({ }^{\circ} \mathrm{C}\right)\end{array}$ & $\begin{array}{l}\text { Gas extraction } \\
\text { time (min) }\end{array}$ & $\begin{array}{l}\text { Oxygen found } \\
\text { (ppm) }\end{array}$ \\
\hline $\mathrm{Co}-1+$ & $\begin{array}{l}1650 \\
1650 \\
1650 \\
1700 \\
1700 \\
1700 \\
1800 \\
1800\end{array}$ & $\begin{array}{r}10 \\
10 \\
10 \\
5 \\
5 \\
5 \\
5 \\
5\end{array}$ & $\begin{array}{l}160 \\
167 \\
161 \\
163 \\
167 \\
165 \\
180 \\
172\end{array}$ \\
\hline $\mathrm{Co}-2 \dagger$ & $\begin{array}{l}1650 \\
1650 \\
1700 \\
1700 \\
1750 \\
1750 \\
1800\end{array}$ & $\begin{array}{r}10 \\
10 \\
5 \\
5 \\
5 \\
5 \\
5\end{array}$ & $\begin{array}{l}29 \\
28 \\
31 \\
33 \\
34 \\
30 \\
30\end{array}$ \\
\hline
\end{tabular}

$\dagger$ Sample taken : $2 \mathrm{~g}$

\section{2 カーボンチップの量}

空浴法で, ニッケル，コバルトの試料約 $2 \mathrm{~g}$ をるつ ぼ内に投入していくと，最初の 2 試料ぐらいは高い定 量值が得られるが，投入回数が多くなるに従ってしだい に低い值が得られることがあった。この原因は明らかで はないが，カーボンと試料との接触性がわるくなり反応 性が遅くなって抽出に時間がかかるためと考光られた。 
そこで試料とカーボンとの接触性をよくするカーボンチ ップをるつぼ内に投入して定量を行ったが，空浴法と 同じく試料を投入していくに従って低い值が得られたの で，毎回試料投入前にカーボンチップをるつぼに投入し て常に新しいカーボンと試料とを接触させる方法を検討 した.

ニッケルの場合のその結果を Table 4 に示す. Table 4 に示すように，カーボンチップを $0.5 \mathrm{~g}$ 投入すると酸 秦抽出量が高くなり，精度よく定量できることを確かめ た. 侹って実際の操作では，試料投入前に常に新しく $0.5 \mathrm{~g}$ のカーボンチップを投入添加し, 脱ガスしてから 試料を投入定量することにした. また，コバルトの場合 も二ッケルと同様な結果が得られたので, 試料投入前に 新しく $0.5 \mathrm{~g}$ のカーボンチップを投入してから試料の定 量を行うことにした。

Table 4 Effect of carbon chips on oxygen values in nickel

\begin{tabular}{ccc}
\hline $\begin{array}{c}\text { Order of carbon chips } \\
\text { and nickel sample } \\
\text { added into bath }\end{array}$ & $\begin{array}{c}\text { Carbon chips or } \\
\text { sample weight } \\
\text { taken (g) }\end{array}$ & $\begin{array}{c}\text { Oxygen found } \dagger \\
(\mathrm{ppm})\end{array}$ \\
\hline Carbon chips & 3.0 & \\
Nickel & 3.12 & 7.5 \\
Nickel & 2.53 & 8.2 \\
Nickel & 3.01 & 7.2 \\
Nickel & 2.50 & 3.1 \\
Carbon chips & 0.5 & \\
Nickel & 2.20 & 6.4 \\
Carbon chips & 0.5 & 7.3 \\
Nickel & 2.61 & \\
Carbon chips & 0.5 & 7.7 \\
Nickel & 2.48 & \\
\hline Gas extraction temperature : $1750^{\circ} \mathrm{C}$ & \\
\hline
\end{tabular}

\section{3 定且結果}

電解ニッケル, Johnson Matthey 製ニッケル，それ をゾーン精製したニッケル，モンドニッケルの各試料 について本法による酸素定量結果を Table 5 に示す.

Table 5 Determination of oxygen in nickel by vacuum fusion method with carbon chip

\begin{tabular}{|c|c|c|c|c|c|c|}
\hline Sample & Oxygen & found & (ppm) & $\bar{x}(\mathrm{ppm})$ & $\sigma(\mathrm{ppm})$ & C. V. $(\%)$ \\
\hline $\mathrm{Ni}-1$ & $\begin{array}{l}44 \\
44 \\
46\end{array}$ & $\begin{array}{l}40 \\
41 \\
45\end{array}$ & $\begin{array}{l}43 \\
42\end{array}$ & 43 & 2.0 & 4.7 \\
\hline $\mathrm{Ni}-2$ & $\begin{array}{l}6.7 \\
7.5 \\
7.2\end{array}$ & $\begin{array}{l}8.0 \\
7.7 \\
7.1\end{array}$ & $\begin{array}{l}8.0 \\
8.3\end{array}$ & 7.6 & 0.42 & 5.6 \\
\hline $\mathrm{Ni}-3$ & $\begin{array}{l}14 \\
13\end{array}$ & $\begin{array}{l}12 \\
15\end{array}$ & $\begin{array}{l}15 \\
15\end{array}$ & 14 & 1.3 & 9.0 \\
\hline $\mathrm{Ni}-4$ & $\begin{array}{l}2.2 \\
2.9\end{array}$ & $\begin{array}{l}2.5 \\
1.8\end{array}$ & $\begin{array}{l}2.3 \\
1.5\end{array}$ & 2.2 & 0.41 & 18.6 \\
\hline
\end{tabular}

Table 5 に示すように酸素含有量 $7.6 \mathrm{ppm}$ の試料に対 するばらつきは，変動係数にして $5.6 \%$, ゾーン精製し た酸素含有量 $2.2 \mathrm{ppm}$ の試料で変動係数は $18.6 \%$ であ った・ほかの試料でもばらつきは变動係数にして10\% 以内であり, 酸素定量の精度としては十分であると思わ れる。

コバルトについての定量結果を Table 6 に示す. 酸 素含有量 $160 \mathrm{ppm}$ の電解コバルト試料に対するばらつ きは，変動係数にして $3.5 \%$, 酸素含有量 $7.5 \mathrm{ppm}$ の ゾーン精製した試料でも変動係数にして $9.2 \%$ であっ た。

Table 6 Determination of oxygen in cobalt by vacuum fusion method with carbon chip

\begin{tabular}{|c|c|c|c|c|c|c|}
\hline Sample & Oxygen & found & (ppm) & $\bar{x}(\mathrm{ppm})$ & $\sigma(\mathrm{ppm})$ & C. V. (\%) \\
\hline Co-1 & $\begin{array}{l}160 \\
162 \\
167\end{array}$ & $\begin{array}{l}161 \\
170 \\
174\end{array}$ & $\begin{array}{l}167 \\
163\end{array}$ & 165 & 5.8 & 3.5 \\
\hline Co 2 & $\begin{array}{l}30 \\
34 \\
34\end{array}$ & $\begin{array}{l}29 \\
25 \\
30\end{array}$ & $\begin{array}{l}23 \\
28\end{array}$ & 29 & 3.9 & 13.4 \\
\hline$(i o-3$ & $\begin{array}{l}6.2 \\
8.0\end{array}$ & $\begin{array}{l}8.8 \\
6.9\end{array}$ & $\begin{array}{l}7.6 \\
7.3\end{array}$ & 7.5 & 0.69 & 9.2 \\
\hline
\end{tabular}

\section{4 鉄浴法, 空浴法との比較}

ニッケル中の酸素定量に関して, 微量酸素の走量法て はないが鉄浴法，あるいは空浴法で行うこ良好な結果が 得られるという報告がある1～3). そこでこれらの方法を 微量酸素に芯用した。すなおち試料重量 $2 \mathrm{~g}$ を使用した とき定量結果を Fig. 1 に示す.

鉄浴法の場合，純鉄 $(20 \sim 30) \mathrm{g}$ 空浴しして使用し

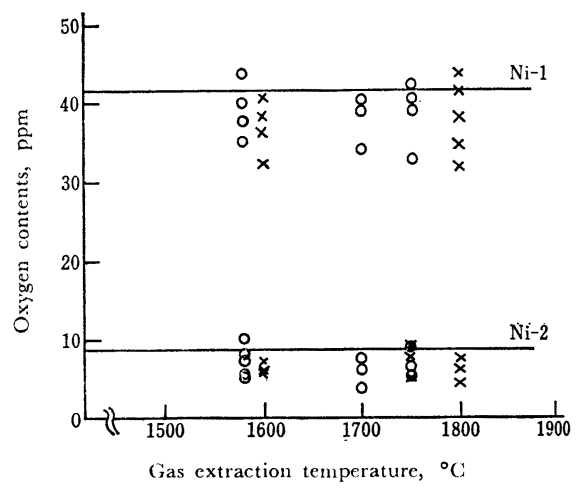

Fig. 1 Determination of oxygen in nickel by vacuum fusion method with iron bath and dry crucible

Iron bath method; $\times$ Dry crucible method; - Mean values by carbon (hip method 
$1570^{\circ} \mathrm{C}, 1700^{\circ} \mathrm{C}, 1750^{\circ} \mathrm{C}$ の抽出温度で，空浴法の場 合, $1600^{\circ} \mathrm{C}, 1750^{\circ} \mathrm{C}, 1800^{\circ} \mathrm{C}$ の抽出温度でそれぞれ試 料 Ni-1，Ni-2 を用いて検討を行った。鉄浴法では， $1700^{\circ} \mathrm{C}, 1750^{\circ} \mathrm{C}$ の各抽出温度では酸素定量值がいずれ も低值を与えるが， $1570^{\circ} \mathrm{C}$ の温度では定量值が高く力 ーボンチップ法による值とかなりよい一致を示したしし かしばらつきが大きく Ni-1 の試料では变動係数にして 15\%，Ni-2 の試料では 20\% であった。 また試料 3 個 目から (50〜70)\% の酸素抽出率になることが多かっ た. 空浴法では, $1600^{\circ} \mathrm{C}, 1800^{\circ} \mathrm{C}$ の抽出温度では低值 を与えるが， $1750^{\circ} \mathrm{C}$ の温度では高い酸素定量值忍得ら れたが，ばらつきが大きく，しかも試料投入順に従って 低い值になる傾向が大きかった。

コバルトの場合もニッケルと闹様, 鉄浴法, 架浴法に つて試料 Co-1，Co-2 を用いて倹討を行った。その 結果を Fig. 2 に示す. 鉄浴法てでは, $1550^{\circ} \mathrm{C}$ の抽出温度 が最も高定量值が得られカーボンチッブ法による值と良 い一致它示したが，ばらつきが大きく Co-1 の試料では 変動係数にして 22\% であった。 そのほかの温度ではい ずれも本法より低い定量值が得られしふもばらつきが大 きかったまた空浴法については， $1600^{\circ} \mathrm{C}, 1700^{\circ} \mathrm{C} の$ 各抽出温度ではいずれも低值を与えたが， $1800^{\circ} \mathrm{C}$ の温 度では酸素抽出量が高く本法による值とよい一致を示し たが，ばらつきが大きく，しかも試料をるつぼに 4 個以 上投入していくと低值を与える傾向があった. ニッケ ル，コバルトいずれも鉄浴法，空浴法で微量酸素尘量す

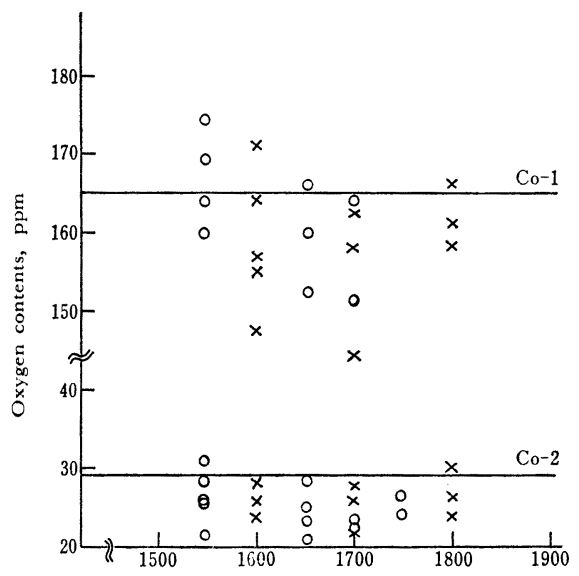

Gas extraction temperature, ${ }^{\circ} \mathrm{C}$

Fig. 2 Determination of oxygen in cobalt by vacuum fusion method with iron bath and dry crucible

Iron bath method; $\times$ Dry crucible method;

- Mean values by carbon chip method
るには種々問題点があるここが分かった。

\section{5 ガス抽出曲線}

一般に金属浴を使用与をと試料々カーボンと爆発的に 反応するのでガス抽出曲線を測定してみると，一つのビ 一クが得られるのみであるが，カーボンチッブを使用す る本法は試料とカーボンとの接触反忘であるので水素, 酸素, 窒素, あるい酸化物の形態によって分離, 異な つた抽出曲線が得られることが本法でも期待される。そ こでニッケルについては，試料 $\mathrm{Ni}-1 ， \mathrm{Ni}-2, \mathrm{Ni}-3$ を用 いて抽出温度 $1750^{\circ} \mathrm{C}$ におけるガス抽出曲線の測爸を行 い，その1例を Fig. 3 に示す. ガス抽出曲線の測定に はガス抽出部に設けたピラニゲージと広領域真空計（考 井归理学機器製）とを朋いた。試料投入直後に現われる ピークは定量するとほとんど水素ガスであるのでこのピ 一クは水素によるものであるが，30 秒後には 2 本のビ 一クが現れる。そしてそのピークの形は試料によって 異なっている. その最初のピークは主に酸素（一酸化炭 素）によるものであるが，後のピークははっきりしてい ない. 試料 $\mathrm{Ni}-1, \mathrm{Ni}-2, \mathrm{Ni}-3$ のそれでれの窒素含存星 は化学分析值で $30 \mathrm{ppm}, 10 \mathrm{ppm}, 4 \mathrm{ppm}$ で, そのピー クの高さと咥素量とに関連があるので空素によるとも考 えられる。しかしほとんど窒素を含まない $\mathrm{Ni}-3$ の試料 でもピークが現れ，先のピークの酸化物と異なった形態 の化合物によるとも考元られるが明らかでない。詳しい ことは更に検討する必要があるように思われる。

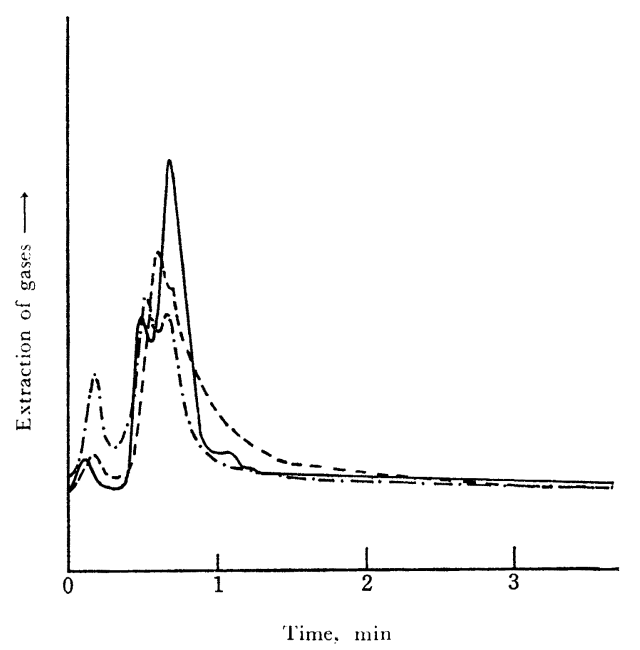

Fig. 3 Extraction curves of gases in nickel at a temperature of $1750^{\circ} \mathrm{C}$ - Ni-1; .... Ni-2; $\ldots-\mathrm{Ni-3}$; Sample taken : $2 \%$ 
コバルトの場合, 試料 Co-1, Co-2 を用いて 抽出温 度 $1750^{\circ} \mathrm{C}$ におけるガス抽出曲線をニッケルの場合と同 様に測定し，その結果の 1 例を Fig. 4 に示す. 試料投 入直後に現れるピークは，ニッケルの場合と同じく水素 によるものであるが， 30 秒後に 現れるピークはニッケ ルとは異なり一つのピークが測定された.

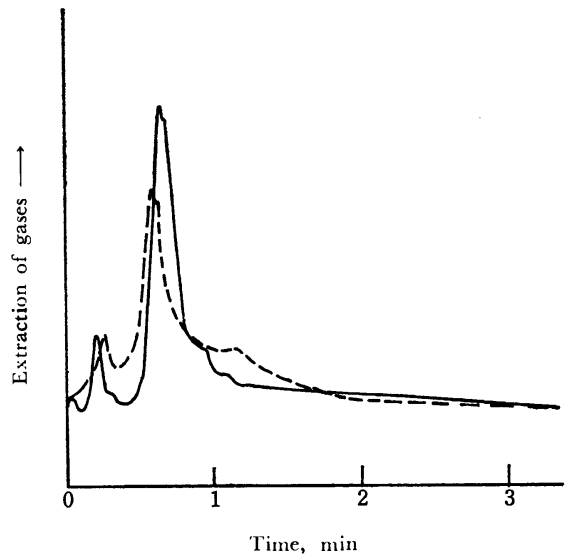

Fig. 4 Extraction curves of gases in cobalt at a temperature of $1750^{\circ} \mathrm{C}$

- Co-1; .... Co-2; Sample taken : $2 \mathrm{~g}$

これらの試料に含有する窒素量は化学分析值で約 25 ppm であったので, 酸素（一酸化炭素）と窒素ともほ とえど同時に抽出されたものと思われる. そしてコバル トの試料では酸化物の存在形態が 1 種類からなっている とも考えられるが試料の酸素含有量が少ないこともあっ てはっきりしないが，この点に関しては今後更に検討す る必要があるように思われる.

終わりに，ゾーン精製の試料の作成をしていただいた 金属材料技術研究所電磁研究部の藤井忠行技官に感謝の 意を表します。

\section{交献}

1) H. H. Sloman :J. Inst. Metals, 71, 391 (1945).
2）村松宏司：金属誌，25，635 (1962)。

3) 柳沢三郎, 関 道治: 本誌, 8, 810 (1959).

4) 須藤恵美子, 斉藤守正, 井上博之：同上, 17, 1364 (1968).

5）須藤恵美子，斉藤守正ほか：同上，17，1369 (1968).

6) 須藤恵美子，斉藤守正 : 同上，17，1482 (1968).

$$
\text { 色 }
$$

Determination of micro oxygen in pure nickel and cobalt by vacuum fusion with carbon chips. Morimasa SAITo and Emiko Sudo (National Research Institute for Metals, 2-3-12, Nakameguro, Meguroku, Tokyo)

In the usual determination of micro amount of oxygen less than $10 \mathrm{ppm}$ in nickel and cobalt, more than 2 grams of the sample is necessary because of the sensitivity of the usual method and of the influence of the blank values from the graphite crucible. However, such a large amount of the sample often gives inaccurate results and incomplete extraction when it is analysed by the conventional method of iron bath and dry crucible. In this paper, a new method using the carbon chips is proposed. The apparatus used in this study was Rigo analyzer for gases in metals S. H. O. II (sensitivity : $0.0055 \mathrm{mg} /$ $\mathrm{mm}$ Oil). The surface of sample was electropolished.

The recommended procedure is as follows : Carbon chips $\{(16 \sim 20)$ mesh $\}, 2$ grams, is previously placed in the crucible and degassed for 5 hours at $2300^{\circ} \mathrm{C}$. After degassing, the crucible temperature is lowered to the gas extraction temperature, $1750^{\circ} \mathrm{C}$ for nickel and $1700^{\circ} \mathrm{C}$ for cobalt, respectively, and then the sample is added to the crucible and gases are extracted and collected for 5 minutes. Before next sample is added to the crucible, carbon chips, 0.5 gram, is added to the crucible and degassed for a few minutes at $2000^{\circ} \mathrm{C}$. Coefficient of deviation of this method was $5.6(\%)$ for electrolytic nickel $(\mathrm{O}$ : $7.6 \mathrm{ppm}$ ), $18.6(\%)$ for zone melted nickel (O : 2.2 ppm) and $9.2(\%)$ for zone melted cobalt (O : 7.5 ppm).

(Received Sept. 6, 1974)

\section{Keywords}

Carbon chip

Micro oxygen in high-purity metals

Vacuum fusion 